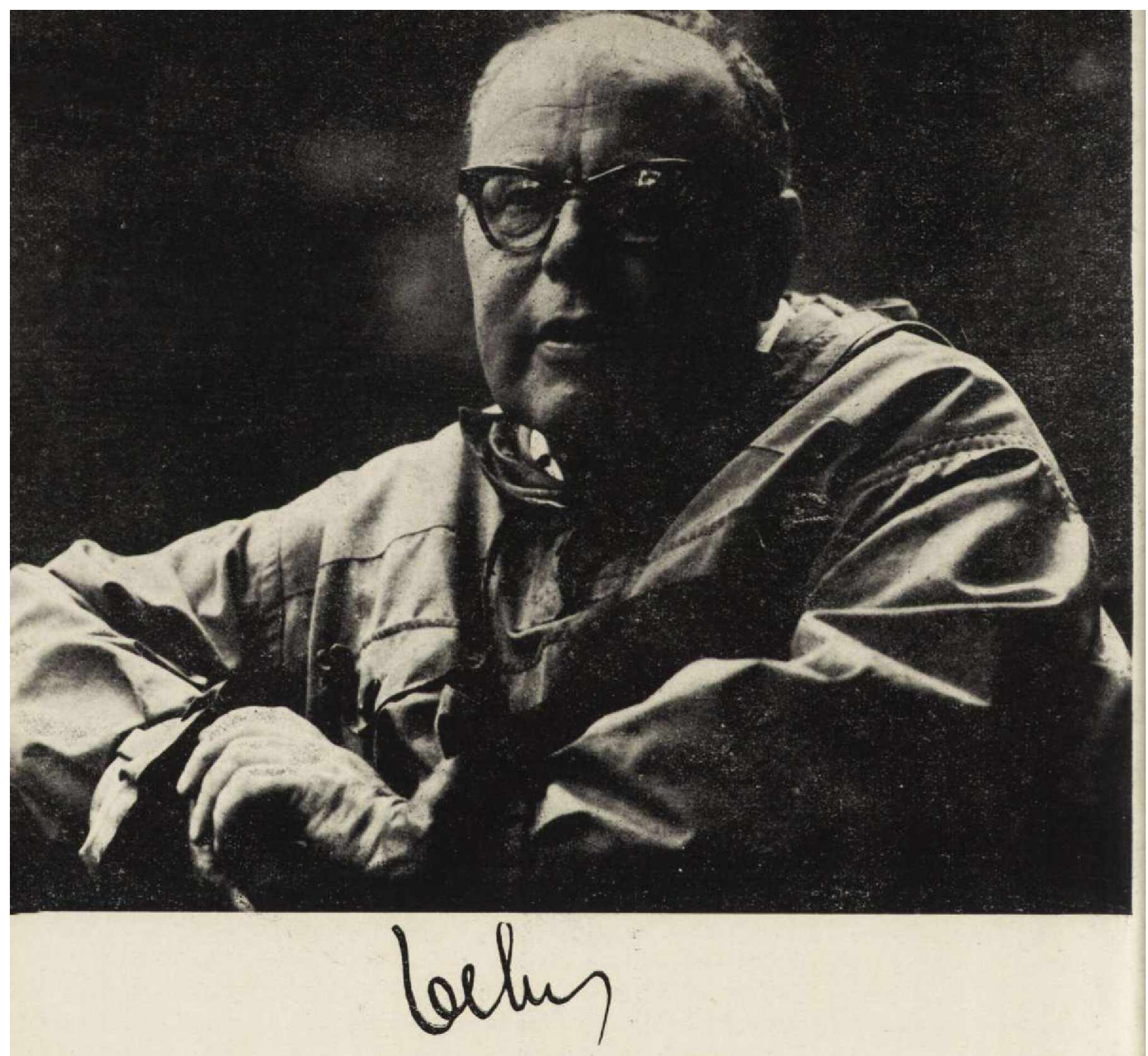




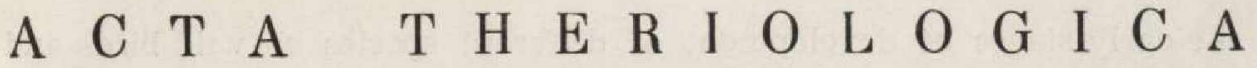 \\ VOL. VIII, $1: 1-10$. \\ BIAŁOWIEŻA \\ 15.X.1964
}

\section{August Dehnel, His Life and Work}

\author{
August Dehnel, życie i dzialalność
}

On November 22nd, 1962 the sudden death was announced of Professor August Dehnel, Ph. D., member-correspondent of the Polish Academy of Sciences, Head of the Mammals Research Institute of the Polish Academy of Sciences at Białowieża and Head of the Department of Comparative Anatomy of Vertebrates of the Maria Curie-Skłodowska University in Lublin.

August Dehnel was born on June 25th, 1903 in Warsaw, the son of a physician, Michał Dehnel, M. D., and Maria née Śliwicka.

In 1922 A. Dehnel began his studies in the Department of Philosophy of Warsaw University. He published his first paper in 1925, and the same year began work in the Institute of Comparative Anatomy of Warsaw University. Under the guidance of the eminent teratologist, Professor Jan $\mathrm{T}$ u r, he wrote his doctoral thesis on the development and genesis of complex monstrosity in the tortoise, and obtained the degree of Doctor of Philosophy in 1926. He continued to hold the post of senior assistant in the Institute until 1935.

During a period of less then ten years (1925-1935) A. Dehnel published 15 studies concerned with the teratology and teratogeny of Sauropsida, and the normal and experimental embryology of birds. He continued to investigate the genesis of complex monstrosities in the mud tortoise. The results which he obtained throw a new light on the origin of complex monstrosities in Emys orbicularis L i n n a e u s, 1758; the source of which may be multi-nuclear eggs ${ }^{110,11]}$. His final work in this field appeared immediately after the second World War, and was the first instance of the development of double monstrosity in Amniota having been observed in live animals.

Dehnel's chief interests, however, lay in the direction of the normal and experimental embryology of birds. He made investigations primarily of 
the early stages of development of different species of wild birds and published 8 studies on this subject during the period from 1926-1929 (see references).

His rich collection of early blastoderms of 35 species belonging to 5 crders of wild birds made it possible for him to arrive at certain general conclusions of an evolutionary character ${ }^{[13]}$. Dehnel distinguished two types of early embryonic stages characteristic of Insessores and Autophagae. Together with J. T u r he published findings on the unevenness of the rate of embryonic development ${ }^{[14]}$.

Professor Dehnel always considered experimental studies to be the most valuable and regarded his efforts in this field as his most important achievements in embryology.

He worked out an original method for splitting hen embryos during the stage of the early primitive streak. The divided embryos were kept in an incubator. They developed and completed the missing elements of the nerve tube, the brain, rudiments of eyes and ears, protosomites and the dorsal cord. The non-geminate organs regenerated the whole of the appropriate systems from half of the material, while the geminate organs regulated the missing organs in a completely different region and from material not intended for this purpose. It was therefore shown that contrary to the views held at that time, birds eggs are endowed with considerable regulating properties ${ }^{[15]}$.

In $1935 \mathrm{~A}$. Dehnel gave up his work at Warsaw University and, failing to find opportunities for further experimental work, decided to alter the direction of his scientific research. He chose a field which did not involve the use of special equipment - the study of the mammal fauna of Poland.

He began his activities in the then State Zoological Museum, first acrumulating what at that time was a very extensive collection (about 3000 specimens) of small mammals from the Polesie district. He made a particular study of representatives of the genus Microtus $\mathrm{S} \mathrm{chrank}$ [19].

From 1937-1939 A. Dehnel was engagend on the protection of the beaver and made investigations of the distribution of this species in Poland. The material he obtained formed the basis for the typescript of a comprehensive study of the biology and distribution of beavers in the basin of the Neman and Pripyat Rivers and book entitled. "Principles of management of beaver reserves". Both typescripts, together with all the supporting documents, were destroyed during hostilities in Warsaw. Dehnel published only a short extract from the first of these two works on the basis of the notes which had been preserved ${ }^{[221}$.

The research work in the field of mammalogy which A. Dehnel had only just begun in 1936 interrupted by the war of 1939-1945.

As a lieutenant A. Dehnel was called up to the army and later taken 
prisoner by the Germans after the September campaign. In the prisoner- of-war camp at Grosborn he gave lectures of biology and organized courses, and was one of the small group of trusted people attached to the Polish camp commandant.

In May 1946 A. Dehnel returned to Poland and began work in the State Zoological Museum as deputy head of the vertebrates section. A year later he was nominated assistant professor at the Maria Curie-Skłodowska University in Lublin, in the Department of Comparative Anatomy of Vertebrates then being organized.

Within the framework of his activities in the Department at Lublin A. Dehnel began work on the mammal material which had been collected at Białowieża since 1946 upon the initiative of the then Director of the Branch of the Forestry Research Institute, Professor J, J. K a r p i ń s k i. This material was of considerable value not only on account of the long series but also on account of the continuity of the collection in different seasons and biotopes. This fact made it possible, even during the first phase, not only to make detailed examination of Polish species of the genus Sorex L., but also to discover the extraordinarily interesting phenomenon of the seasonal variations in the skull of shrews ${ }^{[24]}$, later known in relevant literature as the "Dehnel's phenomenon" (S ch u barth, 1958 and others).

Dehnel discovered that seasonal variations occurred in the height of the brain case in the genus Sorex L. It was also shown in this study that considerable differences exist in colouring and moulting, arrangement of teeth, seasonal fluctuations in the dimensions and weight of the body. A description was also included of a new sub-species (Sorex caecutiens karpinskii $\mathrm{D}$ e $\mathrm{h} \mathrm{n}$ e l, 1949). The paper contained a large number of criticisms of the schematic treatment of the taxonomy of Soricidae and of Micromammalia in general. Several new concepts were put forward which required further investigation and the study formed a starting point for all-round studies of Soricidae and other small mammals, carried out at Białowieża under the leadership of Professor Dehnel by the group of young people, which continued to increase in numbers in successive years.

In the 50s Dehnel continued intensive research on Soricidae. In his study of the genus Neomys $\mathrm{K}$ a u $\mathrm{p}^{[25]}$, in addition to a description of the variations in the skull, body dimensions and moulting, Dehnel discussed in detail and summed up the results of research on Soricidae of the genus Sorex and Neomys.

These studies are closely connected with the work, published jointly with S. B orow ski, "Materials on the biology of Soricidae": [28], which was in principle concerned with three problems: 1 . Individual and seasonal 
variations in body dimensions of 5 species of Soricidae, analysed both during the life cycles and over a period of consecutive years; 2 . variations in selected elements of reproduction in different seasons and years, and 3. population dynamics of Soricidae in 6 yearly capture cycles.

The chief aim of this work was to make a critical estimate of the capture methods in general use and to show the uselessness for ecological purposes of the numerical results obtained in this way. The objections made to capture methods were that they are selective in relation to individuals of different species, different sex and different physiological state. The effect of climatic conditions on captures cannot be compared in different years, or in different section of the study area. In these circumstances "...all capture methods for mammals illustrate only movement and activity...", which is not always directly connected with the actual quantitative relations in the area.

The next study published by Dehnel presented the results of reproduction by shrews under laboratory conditions ${ }^{[26]}$. The breeding of shrews, and even keeping them in cages, is extremely difficult and has not as yet been fully mastered. A. Dehnel succeeded, however, in having coitus and normal births take place in his laboratory colony. Observations made it possible to determine the course taken by sexual maturation, mating and coitus, length of pregnancy and lactation, details of the behaviour of the young shrews while in the nest after birth and for the first few days of their independent life.

Certain additions and supplementary information on the behaviour of shrews under laboratory conditions, with particular attention paid to the collection of food stores, are to be found in the report not published until $1961^{[38] \text {. }}$

The basic concepts of Professor Dehnel's creative thought as a mammalogist are contained in his studies of Soricidae. Foundations were laid for a new trend in mammalogical research, the outline of a critical approach to the collection of material and to the drawing of conclusions from the numerical data obtained became distinct. New all-round plans for the consideration of biological phenomena in the light of the life cycles of each species were created, and emphasis laid on the necessity for using long series of material, obtained over periods of several years.

From 1952-1954 Professor Dehnel, who received financial support from the Academy of Sciences, organized at Białowieża an unofficial field station of the Department of Comparative Anatomy of Vertebrates of the Lublin University. In 1954 this station was taken over by the Polish Academy of Sciences as one of the departments of the Zoological Institute. In the autumn of 1955 Professor A. Dehnel was appointed Head of this La- 
boratory, converted since 1957 into independent Mammals Research Institute, remaining at his post as Head of the Department of Comparative Anatomy of Vertebrates in Lublin until the end of the academic year 1961/62.

From that time on Professor Dehnel devoted all his powers and the whole of his inexhaustible energy to the organisation of this station, which was developing successfully, living and working to bring it into full existence. His untiring efforts brought new increases in staff, accommodation, essential equipment and apparatus. His last years (1959-1962) were absorbed by the erection of the four buildings forming the Institute.

Even in the midst of this overwhelming amount of organising work he found time to direct the scientific side of the Institute, to develop research problems in the direction of physiological ecology, to guide and teach the fairly large group of assistant scientific workers established permanently at Białowieza, or attached to the Institute in order to work on the material collected there.

He also succeeded in finding enough time to establish his own long-term investigations on the natural cross-breeding of the European bison with domestic cattle. He devoted a whole wealth of enthusiasm to this problem; his premature death prevented him from completing the work undertaken.

The preliminary results of these studies ${ }^{[36,39]}$ have already proved to be of great interest, both from the theoretical aspect (inheritance of length of pregnancy and certain morphological and zoopsychological characters, beginning of pregnancy, fecundity of hybrids etc.), and a account of certain prospects of a practical nature (rapid increase in body weight of hybrids $\mathrm{F}_{1}$ ). Hybrids of the domestic bull and female European bison were obtained for the first time in these experiments. This trend in cross-breeding proved to be more promising, if only on account of the easier birth of the hybrid.

Professor Dehnel did not write many popular articles, despite the fact that he liked this kind of activity and appreciated its importance, but those studies and articles, which have been published, particularly "Castles in the water" [23, 34], "A small mammal with a great future" [37] are distinguished by their beautiful literary language and excellent style and are almost entirely based on the author's own observations.

Special emphasis must be laid on a publication, very rare in world literature and unique in more recent Polish literature, that is, a handbook of falconry, originally printed in the form of articles ${ }^{[16]}$ and later, after certain changes and corrections had been made, in book form ${ }^{[17]}$. A. Dehnel was an ardent and highly ethical hunter. He also tamed predatory 
birds, trained them and used them for hawking. To a great extent this work, which is at present a unique bibliographic work, was created from his own observations. It is more than probable that Professor Dehnel was the last falconer to engage in this sport in Poland.

Professor Dehnel devoted a considerable part of his time to editorial work, which he continued uninterruptedly almost immediately after his return from the prisoner-of-war camp (1946), first in the Zoological Institute of the Polish Academy of Sciences, as member of the editing committee of the publications published by this Institute, and editor of a large number of papers, later as member of the editing committee of "Annales Universitatis M. Curie-Skłodowska" and editor of the biological section (C). It was due to his initiative that the periodical "Acta theriologica" was founded, which he edited as from 1958 as the organ of the Mammals Research Institute.

Professor Dehnel took part in the activities of the State Nature Protection Council as member (from 1958), member of the Animal Protection Commission of this Council and consultant of the beaver reserves.

He participated in the activities of several committees of the Polish Academy of Sciences (Ecological, Protection of Nature and its Resources, Zoological). He was member and chairman of the Scientific Council of the Białowieża National Park (as from 1957). He took part in the work of the scientific councils of Warsaw Zoological Garden and of four scientific institutes of the Polish Academy of Sciences.

He was also member of a large number of scientific societies, both Polish and foreign (Polish Zoological Society, the Polish Copernicus Society of Naturalists, Lublin Scientific Society, American Society of Mammalogists, Deutsche Gesellschaft für Säugetierkunde e.V.).

Professor Dehnel represented Polish science at the International Zoological Congress in London (1957) and at the All-Union Congress of Soviet Mammalogists in Moscow (1962). He took part in the annual congresses of the German Mammalogists' Society $(1957,1958,1959)$ in Germany.

For his services in the organising of scientific research and training young research workers Professor Dehnel was awarded the Knight's Cross of the Renaissance of Poland Order, Gold Service Cross and other decorations. He was also awarded a State prize.

As a man Professor Dehnel was endowed with great personal charm, was always unaffected and direct, and had the gift of winning people's confidence and encouraging young scientific workers to collaborate. He was also the valued friend of both simple people and also of his co-workers and colleagues. He found something in common with almost everyone. His influence on a group of people as a whole was extremely strong, he knew how to inculcate not only the proper way of doing scientific work 
but also the essential basic principles of everyday life. He took the trouble to know his co-workers - even the smallest details of their circumstances. It was never a matter of indifference to him whether the students visiting Białowieża were suitably fed and lodged on arrival. He was not one of those "great" and inaccessible professors who are divided by a wide gulf from their assistants and laboratory workers. He could be approached at practically any time of day or night to show results of work, discuss difficulties encountered or everyday personal affairs.

Professor Dehnel's interests apart from his professional ones were mainly humanistic, being a particular admirer of Anatole France and Sholohov. He endeavoured to inculcate a love of books in his fellow workers.

His life was lived intensively, his inexhauestible energy was apparent in all his activities. He was always in a hurry, dealing with a vast amount of affairs, arising from the scientific, editorial and administrative activities of the laboratories of which he was the head. He had no time for rest, for even a short spell of leave. That was how he lived and thus suddenly and unexpectedly he left it all for ever, many years too early, in the full strength of his creative and organising powers.

Polish science has lost an outstanding biologist and mammalogist, a scientific worker with wide horizons of thought formed by the all-powerful influence of comparative and functional anatomy and detailed observation of nature, very critical, with, at the same time, an all-round approach to biological phenomena, gifted with intuition which led him to undertake new and original lines of research and thus create an original trend in mammalogy. His work, both in the field of experimental embryology and mammalogy, and of recent years, of hybridisation, was always distinguished by a touch of something new, advancing our knowledge a step further. Polish science has lost a talented organiser of scientific research, creater and head of two institutes in Lublin and Białowieża.

He has left us for ever but his ideas live on in the minds of those to whom he was both teacher and master, forming the finest and most worthy monument to his memory.

Zdzisław Pucek

\section{LIST OF PUBLICATIONS BY PROF. DR, AUGUST * DEHNEL}

1925

1. Badania nad anomaliami rozwojowemi u żółwia błotnego (Emys orbicularis L.). Pam. 12 Zjazdu Lek. i Przyr. pol. w Warszawie 1925, s. Anat.

*) All embryological papers and popular articles published till 1949 were undersigned by A. Dehnel useing the Christian name - Gustaw. 
2. Origine des polygénèses et oeufs plurinucléés. C. R. Soc. biol., 93: 1205-1206. Paris.

1926

3. O nowszych przypadkach oocytów złożonych w jajniku żólwia Emys orbicularis. Warszawskie Czasop. lek., 2: 1-2. Warszawa.

4. Observations sur le développement du Lyrurus tetrix L. Pam. I Zjazdu Anat.Zool. w Warszawie 1926, 83-84. Warszawa [In Polish].

1927

5. Observations sur l'embryogénie du Coq de bruyère (Lyrurus tetrix L.). C. R. Soc. biol., 97: 529-530. Paris.

6. Sur un cas de diplogénèse très jeune chez le Merle (Planesticus merula merula L.). C. R. Soc. Sci. Lettres de Varsovie, Cl. 3, 20: 558-565. Warszawa [In Polish with French summ.].

7. Sur deux types différents du développement primaire des Oiseaux. C. R. Soc. biol., 99: 1694-1695. Paris.

8. Sur la durée des stades embryonnaires, C. R. Soc, biol., 99: 1696-1697. Paris.

1929

9. Blastotomie expérimentale des germes d'Oiseaux. C. R. Soc. biol., 102: $313-314$. Paris.

10. Recherches sur le développement et la génèse des monstres composés chez la Tortue (Emys arbicularis L.). C. R. Soc. Sci. Lettres de Varsovie, Cl. 4, 22. Warszawa [In Polish with French summ.].

11. Recherches sur le développement et la génès des montres composés chez la Tortue de Polésie (Emys orbicularis L.). Arch. biol. Soc. Sci. Lettres de Varsovie, 2, 2: 1-68. Warszawa [4 pls., 34 figs., In Polish with French summ.].

12. Sur la soi-disant "plaque axiale" dans le développement des Oiseaux. C. R. Soc. biol., 100: 258-259. Paris.

13. Sur les types évolutifs chez les embryons d'Oiseaux. Folia morphol., 1, 1: 1-24. Warszawa [1 tab., 1 pl., In Polish with French summ.].

14. (\& Tur J.) De embryonum evolutionis progressu inaequali. Kosmos, A 53, 4: 86-94. Lwów [In Polish with Latin summ.].

\section{3}

15. Sur les processus régulateurs dans les embryons d'Oiseaux, soumis à la blastotomie artificielle. Kosmos, A 58, 1-4: 53-64. Lwów [1 pl., In Polish with French summ.].

1938

16. O sztuce układania ptaków drapieżnych do łowów. Łowiec pol., 1938: 409-410, $429-431,454-457,481-483,500-502,521-524,541-544$. Warszawa [13 photos, 9 figs.].

17. O sztuce układania ptaków drapieżnych do lowów [On the art of training birds for hunting purposes]. Nakł. "Eowca Polskiego" 1-87. Warszawa [11 photos, 10 figs., In Polish].

18. Ein Beitrag zur Fortpflanzungsbiologie des Hühnerhabichts, Astur gentilis (L. und des Wanderfalgen, Falco peregrinus Tunst. Acta ornithol. Mus. zool. pol. 3, 1: 1-5. Warszawa [In Polish with German summ.].

1946

19. Contribution à la connaissance des représentants du genre Microtus $\mathrm{S} \mathrm{c}$ hr a n $\mathrm{k}$ 
dans les régions de Polesie et de Wilno. Fragm. faun. Mus, zool. pol., 5, 1: 1-24. Warszawa [6 tab., In Polish with French summ.].

1947

20. (\& Kaminski E.) Najpospolitsze gryzonie i sposoby ich zwalczania. [The commonest rodents and methods of its control]. Bibl. Samop. Chłopskiej, 21: $1-63$. Warszawa [1 pl., 15 figs., In Polish].

21. The case of embrionic double monstruality of the turtle (Emys orbicularis L.) observed during its development. Ann. Univ. M. Curie-Sklodowska, Sect. C, 3(1947), 16: 439-454. Lublin [3 figs., In Polish with English summ.].

22. Releve des colonies de Castor fiber vistulanus $\mathrm{M}$ at $\mathrm{s} \mathrm{ch}$ ie dans le bassin supérieur et moyen du Niemen et dans le cours supérieur de la Prypeć en 19371939. Fragm. faun. Mus. zool, pol., 5, 13: 199-224. Warszawa [4 figs., In Polish with French summ.].

1949

23. Zamki na wodzie [Castles in the water]. Książka i Wiedza : 1-66. Warszawa [15 photos, In Polish].

24. Studies on the genus Sorex L. Ann. Univ. M. Curie-Skłodowska, Sect. C, 4, 2: 17-97. Lublin [2 pls., 24 tab., 4 photos, In Polish with English summ.].

\section{0}

25. Studies on the genus Neomys $\mathrm{K}$ a u p. Ann. Univ. M Curie-Skłodowska, Sect. C, 5, 1: 1 -63. Lublin [3 pls., 14 tab., 1 fig., In Polish with English \& Russian summ.].

26. The biology of breeding of Common Shrew, S, araneus L. in laboratory conditions. Ann. Univ. M. Curie-Skłodowska, Sect. C, 6[1951], 11: 359-376. Lublin [1 pl., In Polish with English \& Russian summ.].

27. Zakład Anatomii Porównawczej Kręgowców UMCS w Lublinie. Kosmos, 1, 1: 93-94. Warszawa.

\section{3}

28. (\& Borowski S.) Angaben zur Biologie der Soricidae. Ann. Univ. M. Curie-Skłodowska, Sect. C, 7[1952], 6: 305-448. Lublin [5 figs., 60 tab., In Polish with German \& Russian summ.].

29. Mammals Research Laboratory at Białowieża, Zoological Institute of the Polish Academy of Sciences. Kosmos, A, 4, 2: 336-341. Warszawa [In Polish].

\section{6}

30. Nyctereutes procyonoides (G r a y) - new mammal for Polish fauna. Chronmy Przyr. ojcz, 12, 6: 17-21. Kraków [In Polish].

31. Swoistość badań Białowieskiego Parku Narodowego w ogólnokrajowej sieci parków narołowych i rezerwatów. Sylwan, A 100, 1: 57-58. Warszawa.

\section{7}

32. Ein neues Säugetier der polnischen Fauna Nyctereutes procyonoides G ray. Ann. Univ. M. Curie-Skłodowska, Sect. C, 10, 10: 269-274. Lublin [1 tab., 2 pls.].

1958

33. Mammals Research Institute of the Polish Academy of Sciences, Białowieża, Acta theriol., 2, 14: 300-307. Białowieża.

34. Zamki na wodzie [Castles in the water]. Państw. Zakł. Wyd. Szkol., : 1-75. Warszawa [15 photos, 2nd revised edition]. 
35. The Białowieża National Park. The Beavers. Chrońmy Przyr, ojcz., 15, 2: $44-4-45$. Kraków [1 fig., In Polish].

\section{0}

36. Beobachtungen über das Zusammenleben von Wisent und Hausrind. Acta th theriol., 3, 13: 314-317. Białowieża [1 tab.].

37. A small mammal with a greate future. Poland, 6(70): 28-29. Warszawa [3 pph photos, 1 fig., In English, French, German, Polish, Spanish and Swedish versioonions].

\section{1}

38. Aufspeicherung von Nahrungsvorräten durch Sorex araneus Lin nae us, $117: 1758$. Acta theriol., 4, 14: 265-268. Białowieża.

39. Die ersten Hybriden zwischen Bos taurus dom. L. $\sigma^{\pi}$ und Bison bonasus (L...) L.) ㅇ. Acta theriol., 5, 3: 45-50. Biolowieża [3 photos, 2 pls.].

1962

40. Recherches Scientifiques dans la Forêt de Białowieża. La Pologne, 11(98): $42-3-2-43$. Warszawa [5 photos, In English, French, German, Polish, Spanish and Sweedivedish versions].

\section{BIOGRAPHIC NOTES ON A. DEHNEL}

1. Anonymous, 1963: Wspomnienie o prof. Dehnelu. Przyr. pol., 7, 11: 11. Warszazawzawa.

2. H a n á k, V., 1963: Prof. Dr. August Dehnel. Lynx, 2: 45-46. Praha.

3. Kratochvil, J., 1963: Památce profesora,dr. Augusta Dehnela. Zool. LiLis Listy, 12, 2: 180-181. Brno.

4. Krysia k, K., 1963: August Dehnel (1903-1962). Chrońmy Przyr. ojcz., 1919, 19, 4: 42-43. Kraków.

5. N a s t, J., 1963: August Dehnel (1903-1962). Kosmos, Ser. A, 12, 2: 111- -11-119. Warszawa.

6. N a s t, J., 1963: August Dehnel 1903-1962. Nauka pol., 11, 1: 209-212. Warszazarszawa.

7. Petrusewicz, K., 1963: August Dehnel 25.VI.1903 - 22.XI.1962. Ekol. pl. pol. B 9, 2: 183-185. Warszawa.

8. Pucek, Z., 1963: August Dehnel 25.VI.1903 - 22.XI.1962. Przegl, zool., 7 7,., 7, 4: 317-326. Wrocław.

9. W i j n g a a r d e n, A. van, 1963: In Memoriam Prof. Dr. August Dehnel. Lutritrutra 5: 41. Leiden.

10. Zi mmerma n n, K., 1963: Zum Gedanken an August Dehnel. Ztschr. SäbäuSäugetierkde, 28, 3: 187-188. Hamburg u. Berlin. 